\title{
Identifikasi Variabel Informasi Dalam Framework Inflation Targeting
}

\author{
Juda Agung, Siti Astiyah, Elisabeth Sukowati, \\ Nugroho J. Prastowo, M.Firdauz Muttaqin, Rifqi Ismal ${ }^{*}$
}

\section{Pendahuluan}

Inflation targeting (IT) secara implisit telah diterapkan di Indonesia sejak Bank Indonesia mengumumkan target inflasi secara transparan kepada publik di awal tahun 2000. Penerapan IT di Indonesia didasarkan pada beberapa pertimbangan (Alamsyah, et al, 2001). Pertama, dengan telah ditinggalkannya sistem nilai tukar sebagai nominal anchor, diperlukan adanya anchor alternatif yang kredibel. Kedua, penerapan inflation targeting merupakan konsekuensi dari independensi Bank Indonesia dalam menjalankan kebijakan moneter yang difokuskan pada pengendalian inflasi.

Penerapan inflation targeting di Indonesia terutama jika diterapkan secara "ketat" (strict) masih menimbulkan pro dan kontra. Di satu sisi, komitmen untuk mencapai target inflasi bermanfaat untuk mendisiplinkan bank sentral dalam menjalankan kebijakan moneter, terutama dalam situasi ketika tekanan-tekanan untuk melakukan kebijakan moneter yang akomodatif sangat besar. Bukti empiris di beberapa negara menunjukkan bahwa walaupun inflasi menjadi prioritas, namun ketika 'short-run' trade off antara inflasi dan pertumbuhan ekonomi benar-benar sedang dihadapi, agak sulit bagi otoritas moneter untuk secara konsisten menjadikan inflasi sebagai tujuan utama. Dengan target inflasi yang secara eksplisit diumumkan kepada masyarakat dengan akuntabilitas yang jelas, bank sentral mau tidak mau harus memprioritaskan pencapaian target inflasi. Kebijakan moneter yang secara konsisten memprioritaskan pencapaian target inflasi akan meningkatkan kredibilitas kebijakan moneter itu sendiri, yang pada gilirannya akan menurunkan ekspektasi masyarakat terhadap inflasi dan meminimalisir biaya pengendalian inflasi.

Sementara itu, beberapa pihak yang berkeberatan ${ }^{1}$ diterapkannya inflation targeting di Indonesia pada saat ini mengajukan sejumlah alasan. Pertama, dalam kondisi krisis, base money lebih baik dalam memberikan arah bagi kebijakan moneter karena

\footnotetext{
*) Para penulis mengucapkan terima kasih kepada Direktorat Riset Ekonomi dan Kebijakan Moneter serta Bagian Studi Struktur dan Perkembangan Pasar Keuangan yang telah memberikan saran dan dukungan dalam penyelesaian paper ini 1 Misalnya, Felman (2000).
} 
demand for base money lebih stabil dibandingkan dengan hubungan antara suku bunga dan inflasi. ${ }^{2}$ Dalam kondisi ketidakpastian yang tinggi, suku bunga yang terjadi sangat berfluktuatif sejalan dengan naik turunnya premi resiko sebagai respon terhadap perkembangan faktor-faktor non-fundamental. Kedua, kredibilitas Bank Indonesia lebih mudah dibangun kembali melalui base money targeting karena bank sentral lebih mudah mengendalikan base money dibandingkan mengendalikan inflasi dalam situasi yang serba tidak pasti. Pendapat ini tidak sepenuhnya benar. Pengalaman akhir-akhir ini menunjukkan bahwa pengendalian base money bukanlah hal yang mudah, terutama ketika fungsi intermediasi perbankan tidak berjalan normal dan aktivitas perekonomian berlangsung dengan uang kartal, maka sulit bagi kebijakan moneter untuk menyerap kelebihan base money. Ketiga, dalam situasi dimana banyak kendala di sisi perbankan dan sektor riil, kebijakan moneter untuk mencapai target inflasi sering dihadapkan pada dilemma kebijakan. Karena publik mengetahui dilemma yang dihadapi oleh bank sentral dan memiliki persepsi bahwa bank sentral akan mentolerir laju inflasi untuk tidak mengorbankan sektor riil dan perbankan, ekspektasi masyarakat terhadap inflasi semakin meningkat. Dengan kata lain, karena publik melihat masalah yang dialami oleh perbankan maupun oleh perusahaan adalah masalah jangka pendek yang harus segera diselesaikan, maka publik kurang percaya bahwa bank sentral akan mengabaikannya demi pencapaian target inflasi (credibility problem).

Dengan framework inflation targeting yang saat ini diterapkan, Bank Indonesia masih menggunakan target base money sebagai sasaran antara. Dalam praktek, target inflasi yang diumumkan tersebut digunakan dalam menghitung target base money dengan menggunakan simple quantity theory of money. Beberapa permasalahan dalam pengendalian base money dalam inflation targeting seperti ketidakstabilan hubungan antara base money dan inflasi dan keterbatasan instrumen dalam mengendalikan 'kuantitas' base money telah mendorong berkembangnya wacana tentang perlunya Bank Indonesia untuk segera menerapkan inflation targeting secara penuh (full-fledged inflation targeting). 'Full inflation targeting' mengandung pengertian bahwa kebijakan moneter dalam rangka mencapai target inflasi paling tidak didasarkan pada lima pilar, yaitu tidak adanya nominal anchor lainnya, komitmen institusional untuk mencapai kestabilan harga, tidak adanya dominasi fiskal, instrument independence, dan transparansi dan akuntabilitas (Mishkin dan Hebbel, 2001). Dari kelima pilar IT ini, hanya pilar pertama yang belum dipenuhi dalam framework kebijakan moneter yang saat ini dilakukan, yaitu masih adanya 'double nominal anchor' yaitu digunakannya base money sebagai nominal anchor selain target inflasi itu sendiri. ${ }^{3}$ Lebih dari itu, kebijakan moneter belum sepenuhnya dilakukan secara for-

2 Dalam praktek inflation targeting, sejumlah negara menggunakan Taylor-type rule dalam merespon tekanan inflasi, dimana suku bunga digunakan sebagai operasional target.

3 Sedangkan keempat unsur lainnya secara jelas telah digariskan dalam UU 23/1999. 
ward looking, dalam arti target operasional tidak secara eksplist diarahkan untuk merespon perkembangan inflasi ke depan secara dinamis.

Framework inflation targeting yang bersifat forward looking mensyaratkan kemampuan bank sentral dalam memprediksi perkembangan inflasi ke depan. Studi ini ditujukan untuk mengidentifikasi sejumlah indikator atau variabel yang memiliki kandungan informasi terhadap inflasi ke depan. Dalam konteks inflation targeting informasi terhadap perkembangan inflasi ke depan ini sangat krusial dalam menentukan respon kebijakan moneter, yaitu respon dari target operasional jika perkembangan inflasi ke depan telah melenceng dari target inflasi yang telah ditetapkan.

Kesimpulan dari paper ini adalah sebagai berikut. Pertama, variabel-variabel nilai tukar merupakan 'the best indicators' inflasi dan memberikan efek yang segera terhadap inflasi. Kedua, variabel-variabel suku bunga memiliki information content yang lebih baik terhadap inflasi dibandingkan dengan variabel-variabel kuantitas uang. Temuan ini konsisten dengan berbagai penelitian sebelumnya yaitu suku bunga memiliki information content yang tinggi terhadap inflasi ke depan. Ketiga, output gap mengandung informasi inflasi yang sangat signifikan dan memiliki predictive power terhadap inflasi degan lag antara 12-18 bulan. Ekspektasi inflasi yang dihasilkan dari Survey Kegiatan Dunia Usaha (SKDU) merupakan indikator inflasi dalam jangka pendek, sedangkan dalam jangka panjang kekuatan indikator ini terhadap inflasi melemah.

\section{Inflation Targeting dan Information Variables}

Secara operasional, negara-negara yang telah menerapkan inflation targeting secara penuh seperti UK, Canada, Swedia dan Brazil, menggunakan suatu "rule", seperti Taylor rule dalam merespon terhadap tekanan inflasi ke depan. Secara spesifik, suku bunga yang menjadi stance kebijakan moneter disesuaikan apabila terjadi deviasi antara prakiraan inflasi yang akan datang (forecast inflasi) dengan target inflasi yang telah ditetapkan, dan apabila proyeksi atas aggregat permintaan telah melebihi kapasitas perekonomian.

$$
r=\eta r_{t-1}+\alpha\left(\pi^{f}-\pi^{*}\right)+\beta\left(y-y^{*}\right)
$$

dimana $r$ adalah suku bunga jangka pendek yang dipergunakan sebagai operational target (instrument kebijakan), $\pi f$ dan $\pi^{*}$ adalah inflasi yang akan datang (prakiraan inflasi) dan target inflasi, $y$ dan $y^{*}$ output aktual dan output potensial sehingga $\left(y-y^{*}\right)$ adalah output gap. Suku bunga jangka pendek sebagai instrument moneter tersebut merupakan variabel yang harus dapat dikontrol oleh bank sentral dan akan berubah sebagai respon kebijakan dalam rangka pencapaian sasaran akhir target inflasi. Sehingga dalam rejim inflation tar- 
geting, prakiraan inflasi mempunyai peranan yang penting karena prakiraan inflasi tersebut seringkali menjadi semacam "intermediate target", sehingga kemampuan bank sentral untuk memprediksi inflasi secara tepat menjadi sangat penting. Akan tetapi dalam pengambilan kebijakan untuk merespon jika terjadi deviasi dari target menjadi lebih komplek karena hal ini juga tergantung dari banyak faktor antara lain penentuan dari model yang dipergunakan sehingga permasalahannya tidak sesederhana untuk forecast inflasi saja. Oleh karena itu, banyak negara yang menggunakan inflation targeting juga memerlukan set indicator variables sebagai information variables. Sehingga variables yang mempunyai prediction content dengan inflasi yang akan datang ini menjadi penting untuk membantu pengambil kebijakan.

Secara umum information variables merupakan sebuah set variabel indikator yang mempunyai kandungan informasi untuk memprediksi inflasi yang akan datang. Sebuah variabel dapat berperan sebagai information variabel ataupun sebagai intermediate target, tergantung dari framework kebijakan moneter yang digunakan. Sebagai contoh, nilai tukar dalam rejim nilai tukar tetap merupakan intermediate target, namun dalam rejim nilai tukar fleksibel merupakan information variable. Contoh lain, uang beredar yang berperan sebagai intermediate target dalam framework monetary targeting, dapat berperan sebagai information variable dalam framework inflation targeting.

Peranan dari suatu variable "hanya" sebagai information variable berbeda dengan peranannya sebagai intermediate target ${ }^{4}$. Dalam framework intermediate targeting, variabel tersebut harus memiliki hubungan struktural dengan variabel yang menjadi sasaran akhir yaitu inflasi, lebih dari sekedar memiliki 'forecasting power' atau 'leading indicator' inflasi. Lebih dari itu hubungan struktural tersebut harus stabil. Tentu saja variabel yang menjadi intermediate target harus dapat dikontrol oleh bank sentral melalui instrumen yang dimiliki, sehingga intermediate target itu berupa variabel finansial, seperti suku bunga jangka panjang atau uang beredar.

Sementara itu, variabel yang berperan sebagai information variabel tidak memerlukan hubungan struktural yang stabil dengan inflasi namun cukup memerlukan forecasting power terhadap inflasi. Di samping itu, salah satu keuntungan penggunaan information variable didalam inflation targeting adalah dimungkinkannya untuk memasukkan indikator nonfinansial didalam implementasi kebijakan moneter sehingga dapat meningkatkan efektivitas pencapain sasaran akhir kebijakan moneter. Keuntungan lain dari pendekatan ini adalah bahwa sebuah variabel yang tidak lagi memiliki kandungan informasi inflasi dapat dengan mudah diganti dengan variabel yang lain. Ketidakstabilan hubungan struktural antara uang beredar dengan inflasi dan output pasca deregulasi sektor keuangan di berbagai negara

4 Diskusi lebih detail dapat dilihat di Friedman (1996). 
industri dan berkembang telah menggeser peran uang beredar dari sasaran antara menjadi sekedar information variabel (Friedman dan Kuttner, 1992). Dalam kaitan ini, ketidakpastian transmisi kebijakan moneter dalam suatu periode dimana telah terjadi perubahan struktural dalam perekonomian, penggunaan suatu set information variables dalam kebijakan moneter, daripada menggunakan sebuah variabel sebagai intermediate target, menjadi lebih tepat.

Pendekatan information variable sejalan dengan kerangka inflation targeting yaitu bersifat constrained discretion dan orientasi kebijakan moneter yang bersifat aktif. Berbeda dengan intermediate targeting dimana kebijakan moneter dilakukan secara pasif seperti misalnya Friedman's money supply rule, pendekatan information variables berhubungan dengan penggunaan kebijakan moneter yang aktif seperti dalam inflation targeting dimana respon kebijakan moneter merupakan hasil 'feedback' dari variabel indikator. Information variables ini diharapkan dapat memberikan signal kepada otoritas moneter sehingga otoritas moneter dapat melakukan tindakan preventif jika terjadi "shock" yang dapat mempengaruhi target inflasi. Atas dasar informasi tersebut, otoritas moneter diharapkan dapat merubah policy stance yang diperlukan.

\section{Metodologi dan Data}

\subsection{Metodologi}

Untuk mengidentifikasi suatu variable yang dapat dikelompokkan dalam information variables, yaitu variabel-variabel yang memiliki kandungan informasi terhadap inflasi, studi ini menggunakan berbagai pendekatan. Pertama, untuk melihat hubungan jangka panjang antara variabel-variabel yang menjadi kandidat dengan inflasi, pertama kali dilakukan pengujian kointegrasi. Selain hubungan kointegrasi antara kedua variabel tersebut (bivariate), pengujian kointegrasi juga dilakukan dalam bentuk multivariate dengan melibatkan output riil (trivariate), dan output riil dan nilai tukar (four-variate). Kedua, selanjutnya untuk melihat 'information content' dari variabel-variabel indikator dilakukan 'Granger causality test' dari variabel indikator terhadap inflasi dalam bentuk reduce form persamaan inflasi dalam bentuk first-difference jika antar variabel tidak terdapat hubungan kointegrasi:

$$
\Delta X_{t}=\alpha(L) \Delta X_{t-1}+\beta(L) \Delta Y_{t-1}+\phi(L) \Delta Z_{t-1}+\varepsilon_{t}
$$

atau dalam bentuk model 'error correction' jika antar variabel terdapat hubungan kointegrasi, yaitu dengan menambahkan error correction term ke dalam model (1), menjadi:

$$
\Delta X_{t}=\alpha(L) \Delta X_{t-1}+\beta(L) \Delta Y_{t-1}+\phi(L) \Delta Z_{t-1}+\mathrm{EC}_{t-1}+\varepsilon_{t}
$$


dimana $X$ adalah logaritmik dari indeks harga dan $Y$ adalah variabel indikator. $Z$ adalah vektor dari variabel kontrol yang kemungkinan mengandung informasi terhadap inflasi. Dalam hal ini $\mathrm{Z}$ adalah GDP riil untuk model tiga-variabel dan GDP riil dan nilai tukar untuk model empat-variabel. EC adalah error correction term jika terdapat hubungan kointegrasi antar variabel indikator, indeks harga dan variabel kontrol.

Ketiga, untuk melihat apakah hubungan antara variabel kandidat dan inflasi bersifat 'struktural' dalam arti variabel tersebut penting dalam transmisi kebijakan moneter, studi ini juga menghitung variance decomposition dari inflasi.

\subsection{Data}

Sampel data adalah bulanan 1984.01 - 2001.12. Data inflasi yang digunakan adalah inflasi IHK, inflasi inti dengan menggunakan metode exclusion dan inflasi inti dengan menggunakan metode trimming. Sedangkan variabel-variabel yang digunakan sebagai kandidat terdiri dari 29 variabel yang meliputi besaran moneter, suku bunga, spread, nilai tukar dan variabel di sektor riil seperti output gap dan ekpektasi inflasi. Besaran moneter meliputi base money (BM), uang kartal (CUR), uang beredar dalam arti sempit (M1), uang beredar dalam arti luas (M2), Divisia M1 (DIVM1), dan Divisia M2 (DIVM2). Besaran moneter yang lain meliputi total kredit (CR_TOT), total kredit dengan koreksi nilai tukar (CR_TOTEA), kredit investasi (CR_INV) dan kredit modal kerja (CR_WC). Variabel yang terkait dengan suku bunga meliputi suku bunga SBI 1 bulan (RSBI1M), suku bunga PUAB overnight (RON), suku bunga deposito 1 bulan (RD1) dan 3 bulan (RD3), suku bunga kredit modal kerja (RC_WC) dan suku bunga kredit investasi (RC_INV). Spread suku bunga meliputi spread antara suku bunga kredit dan deposito (SP_CD), spread antara suku bunga deposito dan suku bunga SBI (SP_DS). Sedangkan, nilai tukar meliputi nilai tukar nominal (EXR), Real Effective Exchange Rate (REER), Nominal Effective Exchange Rate (NEER) dan swap rate. Semua data dalam bentuk level di-log-kan terlebih dahulu sebelum digunakan dalam berbagai prosedur empiris. Disamping itu, semua data dihilangkan dari unsur seasonalnya (seasonal adjustment) dengan metode X-12.

Sementara itu, sebelum melakukan pengujian kointegrasi, semua variabel perlu diuji tes stationaritas untuk menganalisa apakah masing-masing variabel tersebut stationer atau non-stationer. Hasil dari uji stationaritas dengan menggunakan prosedur Augmented Dickey-Fuller (ADF) dimana jumlah 'agumented lag' ditentukan sedemikian rupa sehingga residual dari persamaan ADF tidak mengandung serial correlation. Hasil pengujian dengan ADF ini ditampilkan dalam Tabel 1. Tabel 1 mengindikasikan bahwa masing-masing level variabel tidak stasioner, sehingga perlu dilakukan uji stationaritas dengan menggunakan first difference untuk masing-masing variabel. Hasil uji stationaritas dengan menggunakan 
first difference untuk masing-masing variabel tersebut menunjukkan bahwa masing-masing variabel adalah stasioner pada first difference atau masing-masing variabel tersebut berintegrasi order $1(\mathrm{I}(1))$, sehingga valid digunakan untuk pengujian kointegrasi.

Dengan memperhatikan hasil uji stasionaritas, maka pengujian Granger causality menggunakan VAR dalam bentuk first difference. Sedangkan jika terdapat kointegrasi antar variabel, maka Granger causality test untuk melihat information content dari variabelvariabel kandidat dilakukan dengan menggunakan vector error correction, yaitu first difference VAR dengan memasukkan error correction term.

\section{Hasil Empiris}

Hasil dari pengujian kointegrasi dan block exogeneity test (Wald test) untuk mengetahui kandungan informasi terhadap inflasi IHK, exclusion and trimming ditampilkan dalam Tabel 2, Tabel 3 dan Tabel 4 masing-masing untuk sistem dengan dua, tiga dan empat variabel. Hasil pengujian kointegrasi menunjukkan bahwa dalam sistem dua variabel (bivariate system), yaitu variabel informasi dan inflasi, menunjukkan bahwa uang primer, uang kartal, nilai tukar nominal, M1, Divisia M1 dan M2 terkointegrasi dengan ketiga jenis ukuran inflasi . Dalam sistem dengan tiga variabel (trivariate system), maka antara uang primer dan inflasi tidak lagi terkointegrasi, sedangkan variabel lainnya secara konsisten masih terkointegrasi. Namun, dalam sistem dengan empat variabel, yaitu dengan memasukkan nilai tukar ke dalam sistem, beberapa variabel yang sebelumnya terkointegrasi seperti uang primer dan uang kartal menjadi tidak terkointegrasi lagi.

Hasil pengujian dengan Wald test/causality test pada sistem dengan dua variabel untuk melihat kandungan informasi variabel terhadap inflasi mengindikasikan bahwa secara umum baik variabel kuantitas uang seperti uang kartal, M0, M1 dan M2, dan variabelvariabel suku bunga dan nilai tukar mempunyai kandungan informasi terhadap inflasi baik yang diukur dengan IHK maupun terhadap inflasi inti dengan metode exclusion dan trimming. Total kredit, kredit investasi, dan kredit modal kerja juga mempunyai kandungan informasi yang signifikan terhadap inflasi baik yang diukur dengan IHK maupun dengan inflasi inti yang diukur dengan exclusion dan trimming. Akan tetapi hasil uji bivariate Wald test menunjukkan bahwa kredit yang telah dikeluarkan pengaruhnya terhadap volatilitas nilai tukar (CR_TOTEA) tidak mempunyai information content secara significant terhadap inflasi baik yang diukur dari IHK, exclusion maupun trimming. Adanya ketidak konsistenan antara hasil uji total kredit dengan kredit yang telah dikeluarkan faktor perubahan nilai tukarnya mengindikasikan bahwa pengaruh kredit terhadap inflasi kemungkinan melalui pengaruh perubahan nilai tukar. 
Hasil bivariate variance decomposition yang ditampilkan dalam Tabel 5 mendukung hasil dari Granger causality test. Variabel-variabel nilai tukar baik nominal maupun riil, kecuali swap rate, memiliki kemampuan prediksi yang terbesar dalam jangka pendek (6 bulan) dan kamampuan prediksi terhadap inflasi dalam jangka panjang masih relatif tinggi walaupun mengalami penurunan. Sebaliknya, variabel besaran moneter seperti uang kartal, base money, M1, dan M2 serta kredit memiliki kemampuan prediksi yang agak lemah untuk inflasi jangka pendek namun kemampuan prediksinya terhadap inflasi dalam jangka yang relatif lebih panjang menguat dan sangat signifikan di atas 24 bulan. Fakta di atas menunjukkan bahwa transmisi nilai tukar kepada inflasi bersifat segera, sedangkan transmisi uang beredar kepada inflasi memiliki waktu tunda yang relatif lebih lama antara 1-2 tahun.

Mendukung temuan dari uji Granger causality, variance decompisition dari inflasi menunjukkan bahwa total kredit yang sudah dikoreksi dari unsur pergerakan nilai tukar tidak memiliki kemampuan prediktif yang sangat rendah. Sementara itu, variabel suku bunga yang memiliki kemampuan prediksi cukup signifikan terhadap inflasi IHK adalah suku bunga deposito 1 bulan dan suku bunga PUAB overnight. Namun, untuk inflasi inti baik yang dihitung dari exclusion maupun trimming, suku bunga deposito 3 bulan memiliki kemampuan prediksi yang lebih baik dibanding dengan suku bunga deposito 1 bulan.

Walaupun perhitungan output gap dengan metode Hodrick-Prescott sampai saat ini masih banyak mengandung kelemahan, namun kandungan informasi variabel ini terhadap ketiga ukuran inflasi sangat signifikan. Dari variance decomposition inflasi juga menunjukkan bahwa output gap memiliki kemampuan prediktif terhadap inflasi dengan lag antara 1-2 tahun. Sementara itu, ekspektasi inflasi juga mengandung informasi inflasi dalam jangka pendek. Predictive power ekspektasi inflasi menjadi melemah setelah 6 bulan.

Hasil temuan di atas juga konsisten pada sistem dengan tiga variabel. Secara umum tidak ada perbedaan temuan yang signifikan antara sistem dengan dua variabel dan tiga variabel. Hal ini juga tercermin dari temuan bahwa semua variabel nilai tukar, baik nilai tukar nominal (Rp/USD), nominal effective exchange rate (NEER), dan real effective exchange rate (REER) secara konsisten memiliki kandungan informasi yang signifikan terhadap inflasi. Namun demikian, hasil pengujian Granger-causality menunjukkan bahwa kandungan informasi dari base money menjadi lemah dalam trivariate system. Sementara itu, dari hasil trivariate variance decomposition, semakin menunjukkan konsistensi nilai tukar sebagai indikator inflasi baik untuk jangka pendek maupun jangka panjang, sementara predictive power dari beberapa besaran moneter seperti base money, uang kartal, M1 dan M2 mengalami penurunan. Sebaliknya, predictive power dari suku bunga terutama suku bunga PUAB overnight mengalami penguatan dibanding dalam bivariate. 
Hasil pengujian Granger causality dengan empat variabel dalam VAR, yaitu dengan memasukkan nilai tukar nominal ke dalam VAR, ditampilkan dalam Tabel 4, sedangkan four-variable variance decomposition disajikan dalam Tabel 7. Hasil dari Granger causality maupun variance decomposition dengan memasukkan nilai tukar ke dalam sistem menunjukkan perubahan yang cukup signifikan dari information content dan predictive power dari variabel-variabel kandidat. Kandungan informasi terhadap inflasi dari berbagai besaran moneter seperti M1, M2, Divisia M1 dan M2 menjadi hilang. Divisia M1 dan Divisia M2 memiliki kandungan informasi terhadap inflasi inti yang dihasilkan dari metode trimming. Sementara itu, base money dan uang kartal masih memiliki kandungan informasi terhadap semua jenis inflasi namun tidak terkointegrasi dengan inflasi. Temuan ini didukung dengan hasil dari variance decomposition yang menunjukkan bahwa predictive power dari base money dan uang kartal melemah. Hal ini memperkuat fakta tingginya peran nilai tukar dalam mempengaruhi inflasi sehingga peran dari agregat moneter menjadi kurang signifikan. Yang menarik adalah kandungan informasi dari variabel suku bunga menjadi menguat, bahkan predictive power dari suku bunga PUAB melebihi predictive power dari base money baik untuk prediksi inflasi dalam jangka yang lebih pendek (1 tahun) maupun jangka panjang (2-3 tahun). Output gap menjadi variabel yang memiliki predictive power yang tertinggi baik untuk jangka waktu 1, 2 dan 3 tahun ke depan, konsisten untuk semua jenis inflasi.

Untuk mengetahui seberapa lama dampak dari perubahan variabel indikator tersebut akan mempengaruhi inflasi yang akan datang, studi ini menggunakan impulse-response. Impulse-response function ini pada dasarnya digunakan untuk mengetahui time path response dari target variabel dengan adanya 1 unit shock dari variabel besaran moneter tersebut. Pengujian impulse-response function hanya dilakukan untuk variabel besaran moneter yang telah terseleksi mempunyai kandungan informasi yang cukup signifikan terhadap inflasi. Hasil dari pengujian impulse response tersebut ditampilkan dalam grafik 1.

Impulse response function untuk base money mengindikasikan bahwa dampak base money pada inflasi mencapai puncaknya dalam waktu sekitar 24 bulan, sehingga hal ini mengindikasikan bahwa perubahan base money mempunyai informasi untuk memprediksi inflasi baik inflasi IHK, exclusion, dan trimming sekitar 2 tahun kedepan. Impulse response function bivariate untuk uang kartal mengindikasikan perubahan uang kartal mempunyai dampak maksimum terhadap inflasi IHK yang lebih pendek dibdaning base money yaitu sekitar 20-25 bulan ke depan. Impulse response function untuk total kredit signfikan pada periode antara 6 sampai 12 bulan, sedangkan di atas 12 bulan dampaknya tidak signifikan (standar deviasi besar). Sementara itu, impulse response dari inflasi terhadap beberapa besaran moneter lain seperti M1, M2 dan Divisia M2 secara umum mencapai puncak berada pada kisaran antara 18-24 bulan. 
Konsisten dengan hasil variance decomposition, dampak nilai tukar baik nominal maupun REER terhadap inflasi IHK relatif lebih cepat dan mencapai puncaknya pada periode yaitu sekitar 8-12 bulan. Sementara itu, dampak output gap terhadap inflasi sangat signifikan dan mencapai maksimum antara 12-18 bulan.

\section{Kesimpulan}

Dari hasil studi empiris 'information content' sejumlah variabel informasi dapat disimpulkan bahwa: pertama, variabel-variabel nilai tukar merupakan 'the best indicators' inflasi dan memberikan efek yang segera terhadap inflasi. Kedua, variabel kuantitas uang, seperti uang kartal, base money, M1, dan M2 masih memiliki kandungan informasi yang cukup tinggi terhadap inflasi dengan lag sekitar 20-24 bulan. Namun, kandungan informasi aggregat moneter ini melemah ketika nilai tukar dimasukkan sebagai variabel kontrol. Melemahnya kandungan informasi besaran moneter, seperti jumlah uang beredar dan kredit mempunyai implikasi pada pergeseran peran variabel-variabel ini di dalam kebijakan moneter Bank Indonesia, yaitu dari peran sebagai intermediate target menjadi sekedar information variables. Dari variabel aggregate moneter tersebut, base money (M0) mempunyai information content yang cukup besar untuk memprediksi inflasi IHK maupun inflasi inti.

Ketiga, variabel-variabel suku bunga, terutama suku bunga PUAB memiliki kandungan informasi yang lebih baik terhadap inflasi dibandingkan dengan variabelvariabel kuantitas uang. Temuan ini konsisten dengan berbagai penelitian sebelumnya yaitu suku bunga PUAB memiliki information content yang tinggi terhadap inflasi ke depan. Sementara itu, kandungan informasi suku bunga SBI terhadap inflasi sangat lemah.

Keempat, output gap memiliki kandungan informasi yang sangat signifikan dengan dampak yang relatif lebih cepat dibanding besaran moneter yaitu sekitar 12-18 bulan. Kelima, ekspektasi inflasi yang dihasilkan dari Survey Kegiatan Dunia Usaha (SKDU) merupakan indikator inflasi dalam jangka pendek, sedangkan dalam jangka panjang kekuatan indikator ini terhadap inflasi melemah. 
Tabel 1

Unit Root Test

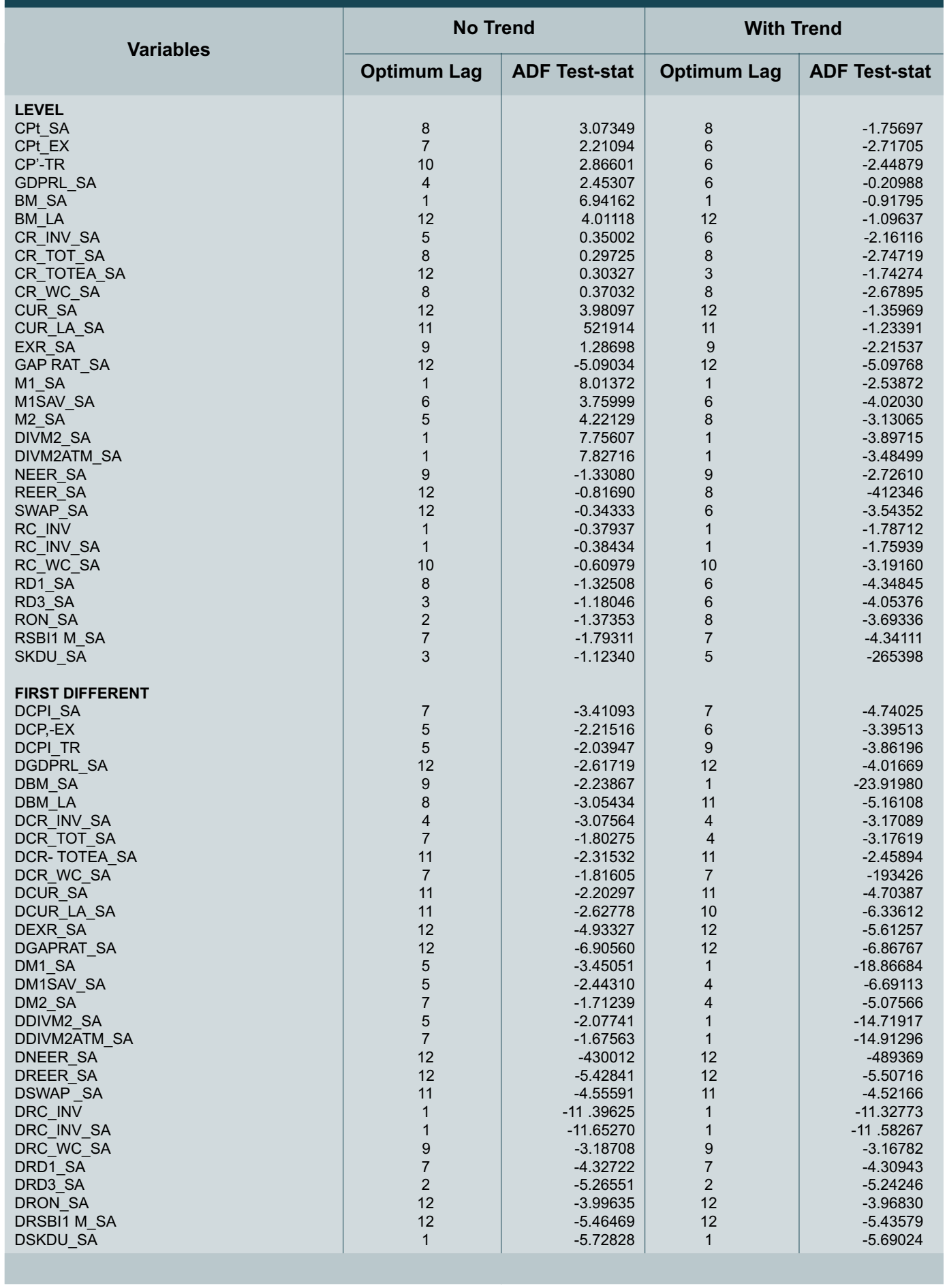


Tabel 2

Kointegrasi dan Casuality (bivariete)

\begin{tabular}{|c|c|c|c|c|c|c|c|c|c|c|}
\hline \multirow{2}{*}{\multicolumn{2}{|c|}{ INFORMATIONS VARIABLES }} & \multicolumn{3}{|c|}{ HEAD LINE } & \multicolumn{3}{|c|}{ EXCLUSION } & \multicolumn{3}{|c|}{ TRIMMING } \\
\hline & & Coint & Wald & ECM & Coint & Wald & ECM & Coint & Wald & ECM \\
\hline $\begin{array}{l}\text { BM } \\
\text { BM_SA }\end{array}$ & Base Money & Yes & 11,19 & $5,51^{\star *}$ & Yes & 9,13 & $9,06^{* \star *}$ & No & 14,38 & - \\
\hline BM_LA & & No & $\begin{array}{c}(0,51) \\
43,51^{* * *} \\
(0,00)\end{array}$ & $(0,02)$ & Yes & $\begin{array}{l}(0,69) \\
30,19- \\
(0,00)\end{array}$ & $\begin{array}{l}7,00) \\
(0,9 S- \\
(0,00)\end{array}$ & Yes & $\begin{array}{c}(0,28) \\
36,50^{\star \star *} \\
(0,00)\end{array}$ & $\begin{array}{l}712^{* * *} \\
(0,08)\end{array}$ \\
\hline $\begin{array}{l}\text { CR_INV } \\
\text { CR_NV_SA }\end{array}$ & Credit - Investment & No & $\begin{array}{c}75,28^{* * *} \\
(0.00)\end{array}$ & - & No & $\begin{array}{c}65,72^{\star * *} \\
(0,00)\end{array}$ & - & No & $\begin{array}{c}52,20^{* * *} \\
(0,00)\end{array}$ & 10.001 \\
\hline $\begin{array}{l}\text { CR_TOT } \\
\text { CR_TOT_SA }\end{array}$ & Credit - Total & No & $\begin{array}{c}75.28^{* * *} \\
(0.00)\end{array}$ & - & No & $\begin{array}{c}66,79^{\star \star *} \\
(0.00)\end{array}$ & - & - & $\begin{array}{c}47,26^{\star \star \star} \\
(0,00)\end{array}$ & - \\
\hline $\begin{array}{l}\text { CR_TOTEA } \\
\text { CR_TOTEA_SA }\end{array}$ & Credit- Total with ER adj & No & $\begin{array}{l}15.37 \\
(0.22)\end{array}$ & - & No & $\begin{array}{l}18,09 \\
(0,11)\end{array}$ & - & No & $\begin{array}{l}10,00) \\
11,81 \\
(0,46)\end{array}$ & - \\
\hline $\begin{array}{l}\text { CR_WC } \\
\text { CR_WC_SA }\end{array}$ & Credit - working capital & No & $\begin{array}{c}41,04^{* * *} \\
(0.00)\end{array}$ & - & No & $\begin{array}{c}63,69^{\star \star \star} \\
(0.00)\end{array}$ & - & No & $\begin{array}{c}43,70^{\star \star *} \\
(0.00)\end{array}$ & - \\
\hline $\begin{array}{l}\text { CUR } \\
\text { CUR_SA }\end{array}$ & Currency & Yes & $\begin{array}{l}13,31 \\
(0,35)\end{array}$ & $\begin{array}{l}5,16^{* *} \\
(0,02)\end{array}$ & Yes & $\begin{array}{c}7,06 \\
(0,85)\end{array}$ & $\begin{array}{l}6,56^{* *} \\
(0,01)\end{array}$ & Yes & $\begin{array}{c}6,70 \\
(0,88)\end{array}$ & $\begin{array}{l}6,26^{* *} \\
(0,012)\end{array}$ \\
\hline CUR_LA_SA & & No & $\begin{array}{c}39,50^{\star \star \star} \\
(0.00)\end{array}$ & & No & $\begin{array}{c}\left(0,78^{\star \star \star}\right. \\
(0,008)\end{array}$ & $(0,01)$ & No & 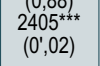 & $(0,012)$ \\
\hline $\begin{array}{l}\text { EXR } \\
\text { EXR_SA }\end{array}$ & Exchange rate nominal & Yes & $\begin{array}{c}95,58^{* * *} \\
(0.00)\end{array}$ & $\begin{array}{l}3.01^{*} \\
(0,08\end{array}$ & No & $\begin{array}{c}287,14^{\star \star \star} \\
(0,00)\end{array}$ & - & No & $\begin{array}{c}270,03^{* * *} \\
(0.00)\end{array}$ & - \\
\hline $\begin{array}{l}\text { GAPRAT } \\
\text { GAPRAT_SA }\end{array}$ & Output gap in ratio terms & No & $\begin{array}{c}33,11^{* * *} \\
(0.00)\end{array}$ & - & No & $\begin{array}{c}33,15^{\star \star *} \\
(0.00)\end{array}$ & - & No & $\begin{array}{c}26,40^{\star \star \star} \\
(0.009)\end{array}$ & \\
\hline M1 1 SA & Narrow Money & Yes & $\begin{array}{c}38.05^{\star \star *} \\
(0,00)\end{array}$ & $\begin{array}{c}16,98^{* * *} \\
(0.00)\end{array}$ & No & $\begin{array}{c}32,29^{* * *} \\
(0.00)\end{array}$ & $\begin{array}{l}757^{\star \star \star} \\
(0.006)\end{array}$ & No & $\begin{array}{c}30,06^{\star \star *} \\
(0.003\end{array}$ & $\begin{array}{l}9.05^{\star \star *} \\
(0.003)\end{array}$ \\
\hline $\begin{array}{l}\text { M1 SAV } \\
\text { M1SAV_SA }\end{array}$ & Na.rrow + Saving deposits & No & $\begin{array}{c}38,62^{\star * *} \\
(0,00)\end{array}$ & - & No & $\begin{array}{c}50,49^{\star \star \star} \\
(0,00)\end{array}$ & - & No & $\begin{array}{c}51,94^{* * *} \\
(0.00)\end{array}$ & - \\
\hline M2 2 SA & Broad money & No & $\begin{array}{c}96.84^{* * *} \\
(0,00)\end{array}$ & - & No & $\begin{array}{c}148,91^{\star * *} \\
(0,00)\end{array}$ & - & No & $\begin{array}{c}139,62^{* \star *} \\
(0,00)\end{array}$ & - \\
\hline $\begin{array}{l}\text { DIVM2 } \\
\text { DIVM2_SA }\end{array}$ & Divisia broad money & Yes & $\begin{array}{c}32.06^{\star * *} \\
(0,00)\end{array}$ & $\begin{array}{c}20,00^{* * *} \\
(0.00)\end{array}$ & Yes & $\begin{array}{c}31,82^{\star \star *} \\
(0,00)\end{array}$ & $\begin{array}{c}1048^{* \star *} \\
(0.00)\end{array}$ & Yes & $\begin{array}{c}33,78^{\star \star \star} \\
(0.00)\end{array}$ & $\begin{array}{c}13,38^{* \star *} \\
(0,00)\end{array}$ \\
\hline $\begin{array}{l}\text { DIVM2ATM } \\
\text { DIVM2ATM_SA }\end{array}$ & Divisia broad moneyadjusled ATM & Yes & $\begin{array}{l}25,82^{\star \star} \\
(0.011)\end{array}$ & $\begin{array}{l}13,31^{* *} \\
(0.00)\end{array}$ & No & $\begin{array}{l}24,70^{* *} \\
(0.016)\end{array}$ & - & Yes & $\begin{array}{l}25,61^{\star *} \\
(0,012)\end{array}$ & $\begin{array}{l}9,04^{\star \star \star} \\
(0.003)\end{array}$ \\
\hline $\begin{array}{l}\text { NEER } \\
\text { NEER_SA }\end{array}$ & Nominal efective exchange rate & No & $\begin{array}{c}207,43^{* \star *} \\
(0.00)\end{array}$ & - & No & $\begin{array}{c}311,62^{* \star \star} \\
(0.00)\end{array}$ & - & No & $\begin{array}{c}262,9^{* * *} \\
(0.00)\end{array}$ & - \\
\hline RC_INV & Loan rate - ivestment & & $\begin{array}{l}24,50^{* *} \\
(0,02)\end{array}$ & - & No & $\begin{array}{l}26,11^{* *} \\
(0,01)\end{array}$ & - & No & $\begin{array}{c}28,58^{\star \star \star} \\
(0,005)\end{array}$ & - \\
\hline RC_NV_SA & & No & $\begin{array}{c}24,85^{\star *} \\
(0.02)\end{array}$ & - & No & $\begin{array}{l}28,09^{* *} \\
(0.007)\end{array}$ & - & No & $\begin{array}{c}28,44^{* * *} \\
(0.005)\end{array}$ & - \\
\hline $\begin{array}{l}\text { RC_WC } \\
\text { RC_WC_SA }\end{array}$ & Loan rate. - working capital & No & $\begin{array}{c}55.30^{* * *} \\
(0.00)\end{array}$ & - & No & $\begin{array}{c}106,33^{* * *} \\
(0.00)\end{array}$ & - & No & $\begin{array}{c}85,19^{\star \star *} \\
(0.00)\end{array}$ & - \\
\hline $\begin{array}{l}\text { RD1 } \\
\text { RDI_SA }\end{array}$ & Deposit rate - 1 month & No & $\begin{array}{c}35,73^{* * *} \\
(0.00)\end{array}$ & - & No & $\begin{array}{c}54,92^{\star \star \star} \\
(0.00)\end{array}$ & - & No & $\begin{array}{c}72,73^{\star \star \star} \\
(0.00)\end{array}$ & - \\
\hline $\begin{array}{l}\text { RD3 } \\
\text { RD3_SA }\end{array}$ & Deposit rate -3 month & No & $\begin{array}{c}30.06^{\star * *} \\
(0.00)\end{array}$ & - & No & $\begin{array}{c}46,53^{\star \star \star} \\
(0.00)\end{array}$ & - & No & $\begin{array}{c}53,83^{* \star *} \\
(0.00)\end{array}$ & - \\
\hline $\begin{array}{l}\text { REER } \\
\text { REER_SA }\end{array}$ & Real effective exchange rate & No & $\begin{array}{c}196,87 * * \star \\
(0.00)\end{array}$ & - & No & $\begin{array}{c}289,17^{* * *} \\
(0.00)\end{array}$ & - & No & $\begin{array}{c}248,81^{* \star *} \\
(0.00)\end{array}$ & - \\
\hline RON & Overnight rate - PUAB & No & $\begin{array}{c}55,81^{* * *} \\
(0.00)\end{array}$ & - & No & $\begin{array}{c}110,03^{* \star *} \\
(0.00)\end{array}$ & - & No & $\begin{array}{c}111,99^{* * *} \\
(0.00)\end{array}$ & - \\
\hline $\begin{array}{l}\text { SBI1M } \\
\text { SBI1M_SA }\end{array}$ & SBI1 month rate & No & $\begin{array}{c}28.84^{* * *} \\
(0.00)\end{array}$ & - & No & $\begin{array}{l}28,05^{\star \star *} \\
(0.005)\end{array}$ & - & No & $\begin{array}{c}30,18^{\star \star \star} \\
(0.003)\end{array}$ & - \\
\hline $\begin{array}{l}\text { SWAP } \\
\text { SWAP_SA }\end{array}$ & Swap rate & No & $\begin{array}{c}78,11^{\star \star *} \\
(0.00)\end{array}$ & - & No & $\begin{array}{c}92,88^{\star \star *} \\
(0.00)\end{array}$ & - & No & $\begin{array}{c}97,11^{\star * \star} \\
(0.00)\end{array}$ & - \\
\hline $\begin{array}{l}\text { SKDU } \\
\text { SKDU_SA }\end{array}$ & Survey in Business Sector Activily & No & $\begin{array}{c}42,89^{* * *} \\
(0.00)\end{array}$ & - & No & $\begin{array}{c}42,13^{\star * *} \\
(0.00)\end{array}$ & - & No & $\begin{array}{c}49,13^{\star \star *} \\
(0.00)\end{array}$ & - \\
\hline
\end{tabular}

Note

$\left.{ }^{*}\right)$ Significant at $\alpha=10 \%$ or $90 \%$ level of confidence ${ }^{* *}$ ) Significant at $\alpha=5 \%$ or $95 \%$ level of confidence ${ }^{* * *}$ ) Significant at $\alpha=1 \%$ or $99 \%$ level of confidence 
Tabel 3

Kointegrasi dan Casuality (trivariete)

\begin{tabular}{|c|c|c|c|c|c|c|c|c|c|c|}
\hline \multirow{2}{*}{\multicolumn{2}{|c|}{ INFORMATIONS VARIABLES }} & \multicolumn{3}{|c|}{ HEAD LINE } & \multicolumn{3}{|c|}{ EXCLUSION } & \multicolumn{3}{|c|}{ TRIMMING } \\
\hline & & Coint & Wald & ECM & Coint & Wald & ECM & Coint & Wald & ECM \\
\hline $\begin{array}{l}\text { BM } \\
\text { BM_SA } \\
\text { BM_LA }\end{array}$ & Base Money & $\begin{array}{l}\text { No } \\
\text { No }\end{array}$ & $\begin{array}{c}20,77^{\star \star *} \\
(0,054) \\
35,23^{\star * *} \\
(0,00)\end{array}$ & - & $\begin{array}{l}\text { Yes } \\
\text { Yes }\end{array}$ & $\begin{array}{l}7,54 \\
(0,82) \\
17,00 \\
(0,15)\end{array}$ & $\begin{array}{c}4,37^{\star *} \\
(0,04) \\
409^{\star * \star} \\
(0.04)\end{array}$ & $\begin{array}{l}\text { No } \\
\text { Yes }\end{array}$ & $\begin{array}{l}11,32 \\
(0,50) \\
20,24^{*} \\
(0,06)\end{array}$ & $\begin{array}{c}\cdot \\
348^{*} \\
(0.06)\end{array}$ \\
\hline $\begin{array}{l}\text { CR_INV } \\
\text { CR_INV_SA }\end{array}$ & Credit - Investment & No & $\begin{array}{c}68,89^{* * *} \\
(0,00)\end{array}$ & - & No & $\begin{array}{c}74,97^{\star * *} \\
(0,00)\end{array}$ & $\begin{array}{c}(0.04) \\
-\end{array}$ & No & $\begin{array}{c}(0,00) \\
59,54^{\star \star \star} \\
(0.00)\end{array}$ & - \\
\hline $\begin{array}{l}\text { CR_TOT } \\
\text { CR_TOT_SA }\end{array}$ & Credit - Total & No & $\begin{array}{c}49,76^{* * *} \\
(0.00)\end{array}$ & - & No & $\begin{array}{c}8180^{* * *} \\
(0.00)\end{array}$ & $\cdot$ & No & $\begin{array}{c}54,12^{\star * *} \\
(0.00)\end{array}$ & $\cdot$ \\
\hline $\begin{array}{l}\text { CR_TOTEA } \\
\text { CR_TOTEA_SA }\end{array}$ & Credit - Total with ER adj & No & $\begin{array}{l}12.42 \\
(0.41)\end{array}$ & - & No & $\begin{array}{l}19.41^{*} \\
(0.08)\end{array}$ & $\cdot$ & No & $\begin{array}{r}14,58 \\
(0.27)\end{array}$ & $\cdot$ \\
\hline $\begin{array}{l}\text { CR_WC } \\
\text { CR_WC_SA }\end{array}$ & Credit - working capital & No & $\begin{array}{c}41.12^{\star * *} \\
(0.00)\end{array}$ & - & No & $\begin{array}{c}74,77^{\star * *} \\
(0,00)\end{array}$ & - & No & $\begin{array}{c}(0.21) \\
46,92^{\star * *} \\
(0,00)\end{array}$ & - \\
\hline $\begin{array}{l}\text { CUR } \\
\text { CUR_SA }\end{array}$ & Currency & Yes & $\begin{array}{r}11,33 \\
(0,50)\end{array}$ & $\begin{array}{l}2,92^{*} \\
(0,09)\end{array}$ & Yes & $\begin{array}{r}6,58 \\
(0,88)\end{array}$ & $\begin{array}{l}5,45^{\star *} \\
(0,02)\end{array}$ & Yes & $\begin{array}{c}8,18 \\
(0,77)\end{array}$ & $\begin{array}{l}5,51^{* *} \\
(0,02)\end{array}$ \\
\hline CUR_LA_SA & & No & $\begin{array}{l}28,78^{* \star * *} \\
(0,004)\end{array}$ & - & No & $\begin{array}{l}17,41 \\
(0,13)\end{array}$ & $10,-1$ & No & $\begin{array}{l}17,15 \\
(0,14)\end{array}$ & - \\
\hline $\begin{array}{l}\text { EXR } \\
\text { EXR_SA }\end{array}$ & Exchange rate nominal & Yes & $\begin{array}{c}42,26^{* * *} \\
(0,00)\end{array}$ & $\begin{array}{l}8,03^{\star * *} \\
(0,005)\end{array}$ & Yes & $\begin{array}{c}76,16^{* \star *} \\
(0.00)\end{array}$ & $\begin{array}{l}6,74^{\star \star \star} \\
(0,009)\end{array}$ & Yes & $\begin{array}{c}76,91^{\star \star *} \\
(0.00)\end{array}$ & $\begin{array}{l}3,87^{\star *} \\
(0,045)\end{array}$ \\
\hline $\begin{array}{l}\text { GAPRAT } \\
\text { GAPRAT_SA }\end{array}$ & Output gap in ratio terms & No & $\begin{array}{c}32.12^{\star \star *} \\
(0,00)\end{array}$ & - & No & $\begin{array}{l}20,16^{*} \\
(0.06)\end{array}$ & - & No & $\begin{array}{l}19,46^{*} \\
(0.08)\end{array}$ & $\cdot$ \\
\hline $\begin{array}{l}\text { M1 } \\
\text { M1_SA }\end{array}$ & Narrow Money & Yes & $\begin{array}{l}26,06^{\star \star} \\
(0,011)\end{array}$ & $\begin{array}{c}12,60^{\star * *} \\
(0,00)\end{array}$ & Yes & $\begin{array}{l}17,71 \\
(0,12)\end{array}$ & $\begin{array}{l}6,96 * * \\
(0.008)\end{array}$ & Yes & $\begin{array}{l}17,88 \\
(0,12)\end{array}$ & $\begin{array}{c}9,72 \\
(0,00)\end{array}$ \\
\hline $\begin{array}{l}\text { M1SAV } \\
\text { M1SAV_SA }\end{array}$ & Narrow + Saving deposits & No & $\begin{array}{l}21.24^{\star \star} \\
(0,047)\end{array}$ & - & No & $\begin{array}{c}34,16^{\star \star *} \\
(0,00)\end{array}$ & - & No & $\begin{array}{c}34,27^{\star \star *} \\
(0,00)\end{array}$ & - \\
\hline M2 & Broad money & No & $\begin{array}{c}86.79^{* \star *} \\
(0.00)\end{array}$ & - & No & $\begin{array}{c}138,75^{\star \star *} \\
(0.00)\end{array}$ & $\cdot$ & No & $\begin{array}{c}135,71^{* * *} \\
(0.00)\end{array}$ & - \\
\hline $\begin{array}{l}\text { DIVM2 } \\
\text { DIVM2_SA }\end{array}$ & Divisia broad money & Yes & $\begin{array}{l}25,02^{* *} \\
(0.015)\end{array}$ & $\begin{array}{c}10,02^{* * *} \\
(0,00)\end{array}$ & Yes & $\begin{array}{l}22,17^{\star *} \\
(0.04)\end{array}$ & $\begin{array}{l}4.86^{* *} \\
(0.03)\end{array}$ & Yes & $\begin{array}{l}25.86^{* *} \\
(0.011)\end{array}$ & $\begin{array}{r}5.96^{* *} \\
(0.015)\end{array}$ \\
\hline $\begin{array}{l}\text { DIVU2ATIIII } \\
\text { DIVM2ATIII_SA }\end{array}$ & Divisia broad money adjusted ATM & Yes & $\begin{array}{l}22.69^{* \star} \\
(0.03)\end{array}$ & $\begin{array}{l}8.87^{\star *} \\
(0.03)\end{array}$ & No & $\begin{array}{l}17.11 \\
(0.15)\end{array}$ & - & Yes & $\begin{array}{l}19.91^{*} \\
(0.07)\end{array}$ & $\begin{array}{l}4.02^{\star \star} \\
(0.045)\end{array}$ \\
\hline $\begin{array}{l}\text { NEER } \\
\text { NEER_SA }\end{array}$ & Nominal efective exchange rate & Yes & $\begin{array}{c}36,44^{* * *} \\
(0.00)\end{array}$ & $\begin{array}{l}3,98^{* *} \\
(0.045)\end{array}$ & Yes & $\begin{array}{c}72,49^{\star \star *} \\
(0.00)\end{array}$ & $\begin{array}{l}7,16^{\star * *} \\
(0.007)\end{array}$ & Yes & $\begin{array}{c}186,91^{\star \star \star *} \\
(0.00)\end{array}$ & - \\
\hline RCJNV & Loan rate - investment & No & $\begin{array}{c}33,72^{* * *} \\
(0,00)\end{array}$ & - & No & $\begin{array}{l}29,09^{* * *} \\
(0,004)\end{array}$ & $\cdot$ & No & $\begin{array}{c}32,06^{* * *} \\
(0,00)\end{array}$ & - \\
\hline $\begin{array}{l}\text { RC_INV_SA } \\
\text { RC WC }\end{array}$ & & No & $\begin{array}{c}34,31 * * \star \\
(0.00)\end{array}$ & - & No & $\begin{array}{c}30,22^{* * *} \\
(0.003)\end{array}$ & - & No & $\begin{array}{c}33,55^{\star * *} \\
(0.00)\end{array}$ & - \\
\hline $\begin{array}{l}\text { RC_WC } \\
\text { RC_WC_SA }\end{array}$ & Loan rate - working capital & No & $\begin{array}{c}54.27 * * * \\
(0.00)\end{array}$ & - & No & $\begin{array}{c}85,62^{\star \star \star} \\
(0.00)\end{array}$ & - & No & $\begin{array}{c}77,40^{\star \star *} \\
(0.00)\end{array}$ & $\cdot$ \\
\hline $\begin{array}{l}\text { RD1 } \\
\text { RD1_SA }\end{array}$ & Deposit rate - 1 month & No & $\begin{array}{c}45.51^{* \star *} \\
(0.00)\end{array}$ & - & No & $\begin{array}{l}51.77^{\star \star *} \\
(0.00)\end{array}$ & - & No & $\begin{array}{c}56,94^{\star * *} \\
(0.00)\end{array}$ & - \\
\hline $\begin{array}{l}\text { RD3 } \\
\text { RD3_SA }\end{array}$ & Deposit rate -3 month & No & $\begin{array}{c}35.65^{\star \star *} \\
(0.00)\end{array}$ & - & No & $\begin{array}{l}32,73^{* * *} \\
(0,001)\end{array}$ & - & No & $\begin{array}{c}37,31^{* * *} \\
(0,00)\end{array}$ & - \\
\hline $\begin{array}{l}\text { REER } \\
\text { REER_SA }\end{array}$ & Real effective exchange rate & No & $\begin{array}{c}146.10^{* \star *} \\
(0.00)\end{array}$ & - & No & $\begin{array}{c}239,83 * * * \\
(0.00)\end{array}$ & - & No & $\begin{array}{c}179,79^{* * *} \\
(0.00)\end{array}$ & - \\
\hline $\begin{array}{l}\text { RON } \\
\text { RON_SA }\end{array}$ & Overnight rate - PUAB & No & $\begin{array}{c}59.26^{* * *} \\
(0.00)\end{array}$ & - & No & $\begin{array}{c}88.44^{* * *} \\
(0.00)\end{array}$ & - & No & $\begin{array}{c}77,12^{\star * *} \\
(0.00)\end{array}$ & - \\
\hline $\begin{array}{l}\text { SBI1M } \\
\text { SBI1M_SA }\end{array}$ & SBI1 month rate & No & $\begin{array}{c}30.93^{* * *} \\
(0.002)\end{array}$ & - & No & $\begin{array}{l}3200^{* * *} \\
(0.001)\end{array}$ & - & No & $\begin{array}{c}29,90^{\star \star *} \\
(0,003)\end{array}$ & - \\
\hline $\begin{array}{l}\text { SWAP } \\
\text { SWAP_SA }\end{array}$ & Swap rate & No & $\begin{array}{c}70.76^{* \star *} \\
(0.00)\end{array}$ & - & No & $\begin{array}{c}77.63^{\star * *} \\
(0.00)\end{array}$ & - & No & $\begin{array}{c}93,18^{* * *} \\
(0.00)\end{array}$ & $\cdot$ \\
\hline $\begin{array}{l}\text { SKDU } \\
\text { SKDU_SA }\end{array}$ & Survay in Business Sector Activity & No & $\begin{array}{c}26.07^{\star *} \\
(0.01)\end{array}$ & - & No & $\begin{array}{c}21,67^{\star *} \\
(0,04)\end{array}$ & - & No & $\begin{array}{c}28,56^{\star * *} \\
(0,005)\end{array}$ & - \\
\hline
\end{tabular}

*) Significant at $\alpha=10 \%$ or $90 \%$ level of confidence ${ }^{* *}$ ) Significant at $\alpha=5 \%$ or $95 \%$ level of confidence ${ }^{* * *}$ ) Significant at $\alpha=1 \%$ or $99 \%$ level of confidence 


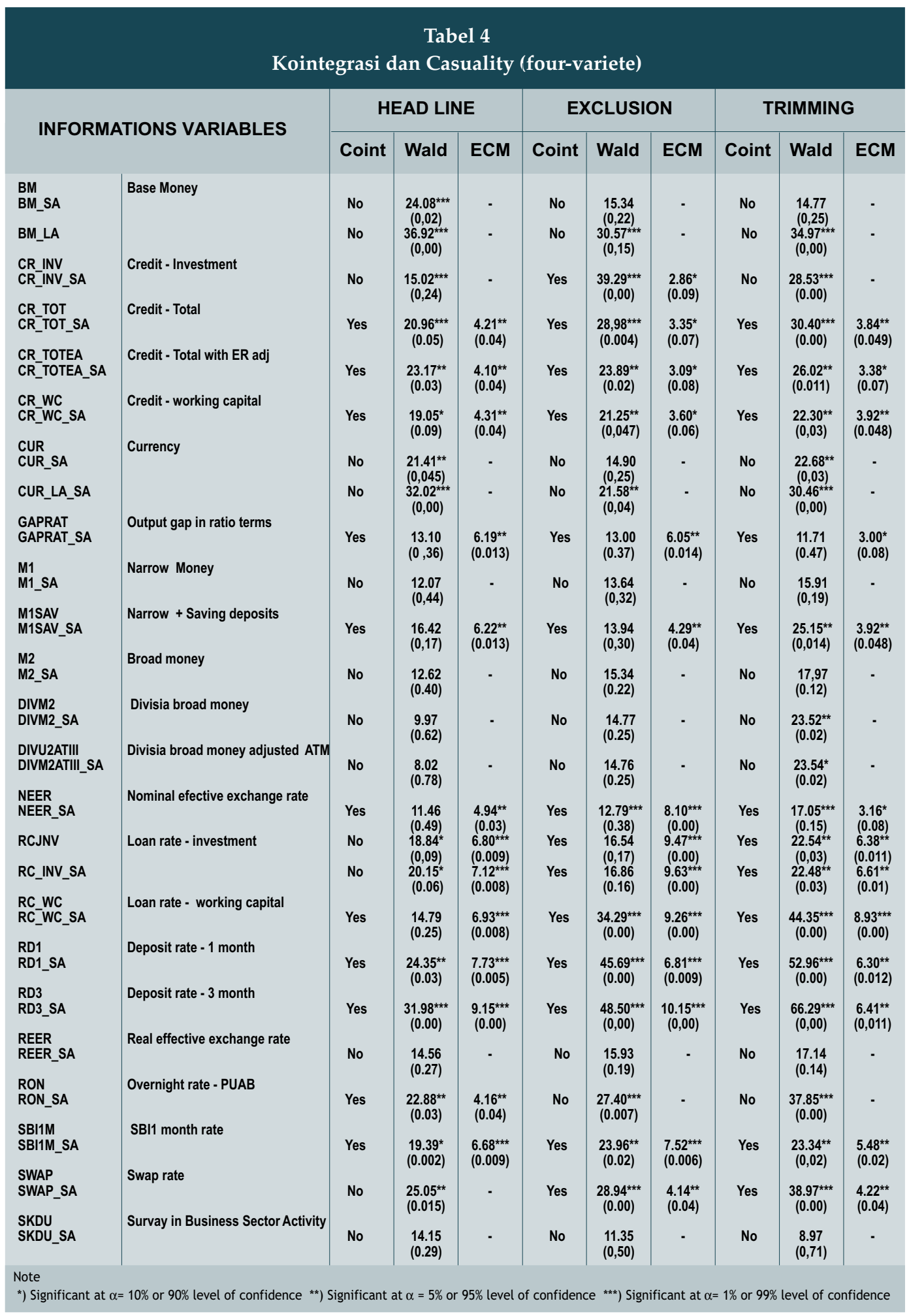




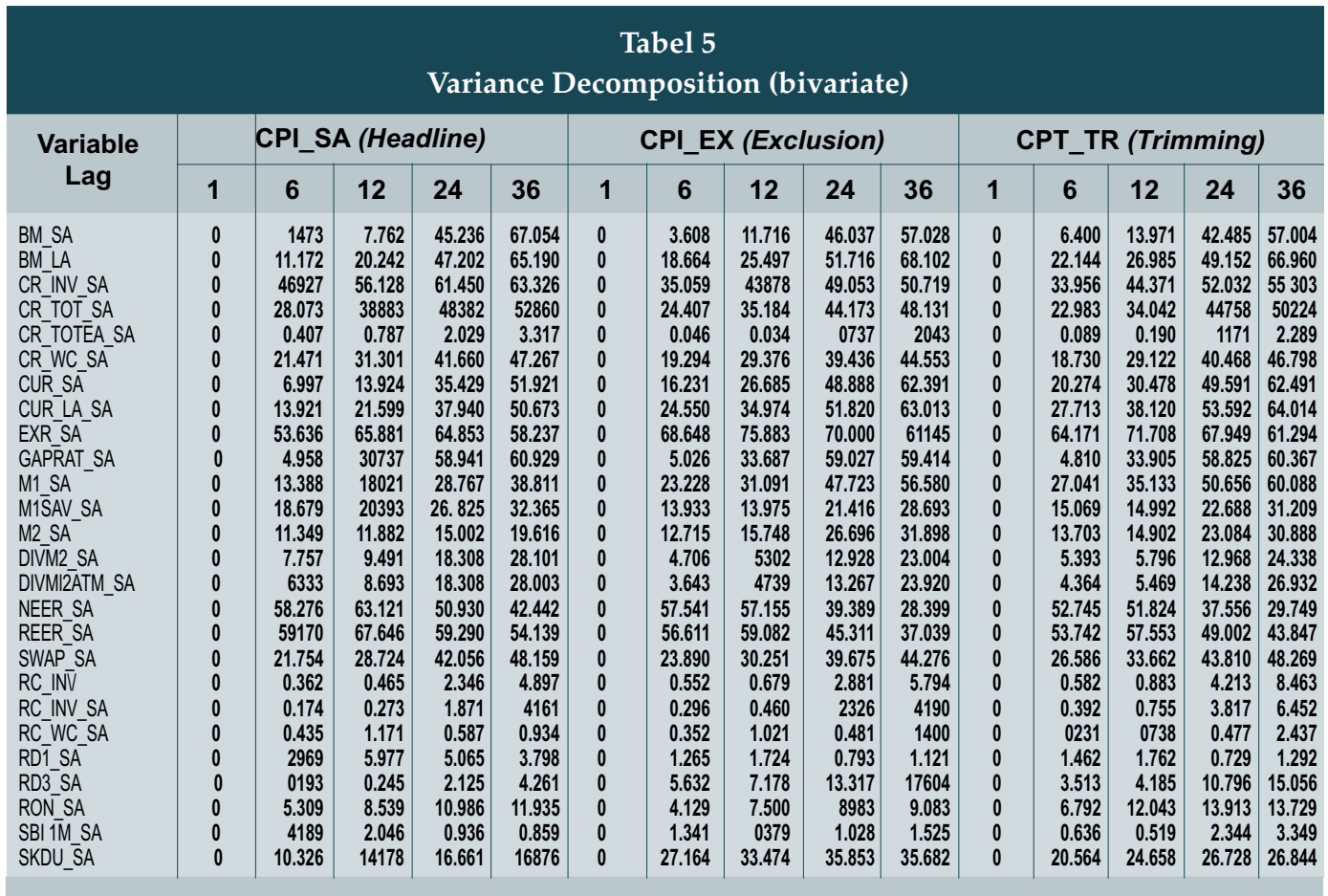

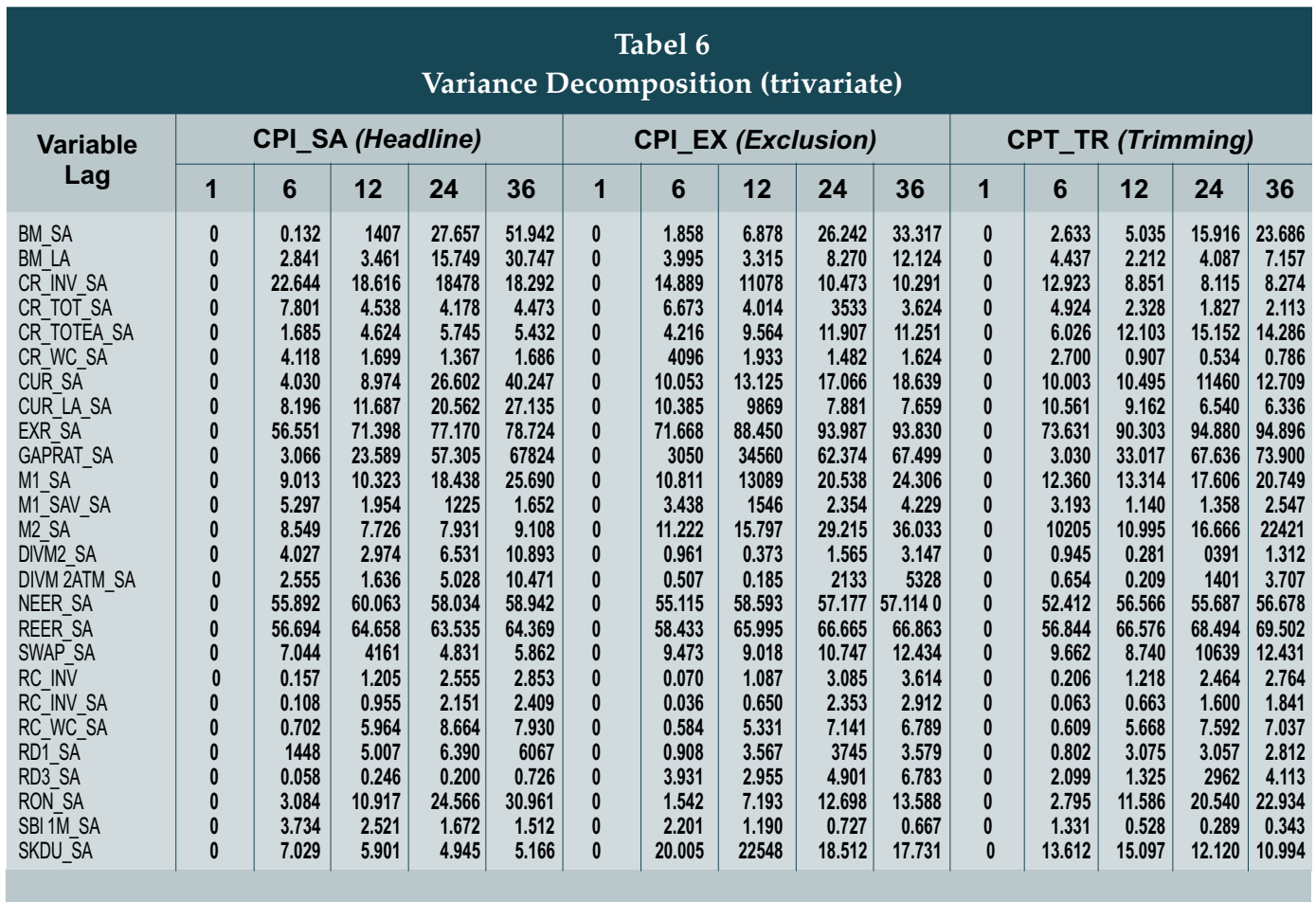




\begin{tabular}{|c|c|c|c|c|c|c|c|c|c|c|c|c|c|c|c|}
\hline \multirow{3}{*}{$\begin{array}{l}\text { Variable/ } \\
\text { Lag }\end{array}$} & \multicolumn{10}{|c|}{$\begin{array}{l}\text { Tabel } 7 \\
\text { Variance decomposition (four-variable) }\end{array}$} & & & & & \\
\hline & \multicolumn{5}{|c|}{ CPI_SA (Headline) } & \multicolumn{5}{|c|}{ CPI_EX (Exclusion) } & \multicolumn{5}{|c|}{ CPT_TR (Trimming) } \\
\hline & 1 & 6 & 12 & 24 & 36 & 1 & 6 & 12 & 24 & 36 & 1 & 6 & 12 & 24 & 36 \\
\hline BM_SA & 0 & 1.062 & 0.668 & 15.785 & 32.750 & 0 & 0.017 & 2.093 & 20.984 & 30.223 & 0 & 0.099 & 1.040 & 12.768 & 22.325 \\
\hline BM_LA & 0 & 0.805 & 0.640 & 4.739 & 17.098 & 0 & 0.964 & 0.869 & 3.240 & 7.420 & 0 & 1.464 & 1.148 & 1.274 & 4.260 \\
\hline CR_INV_SA & 0 & 0.237 & 0.827 & 0.607 & 0.961 & 0 & 0.497 & 0.336 & 0.569 & 1.109 & 0 & 0.201 & 0.280 & 1.582 & 2.474 \\
\hline CR_TOT_SA & 0 & 1.553 & 2.399 & 1.672 & 1.899 & 0 & 2.979 & 2.672 & 1.685 & 1.805 & 0 & 2.985 & 0.993 & 0.741 & 1.145 \\
\hline CR_TOTEA_SA & 0 & 0.947 & 0.795 & 0.487 & 0.711 & 0 & 1.909 & 1.289 & 0.811 & 0.918 & 0 & 1.428 & 0.360 & 0.760 & 1.086 \\
\hline CR_WC_SA & 0 & 2.172 & 2.317 & 1.511 & 1.699 & 0 & 4.106 & 3.818 & 2.481 & 2.419 & 0 & 4.215 & 1.644 & 0.938 & 1.193 \\
\hline CUR_SA & 0 & 0.443 & 1.675 & 8.157 & 14.453 & 0 & 0.272 & 0.064 & 0.615 & 1.494 & 0 & 0.635 & 0.261 & 0.192 & 0.663 \\
\hline CUR_LA_SA & 0 & 0.500 & 0.115 & 0.708 & 2.278 & 0 & 0.356 & 1.078 & 3.295 & 3.376 & 0 & 0.599 & 1.546 & 4.990 & 5.192 \\
\hline EXR_SA & 0 & 56.551 & 71.398 & 77.170 & 78.724 & 0 & 71.668 & 88.450 & 93.987 & 93.830 & 0 & 73.631 & 90.303 & 94.880 & 94.896 \\
\hline GAPRAT_SA & 0 & 0.711 & 18.380 & 53.279 & 64.273 & 0 & 0.971 & 31.387 & 65.923 & 70.476 & 0 & 1.051 & 31.542 & 69.226 & 73.745 \\
\hline M1_SA & 0 & 0.765 & 0.169 & 1.648 & 5.792 & 0 & 0.642 & 0.322 & 1.708 & 5.182 & 0 & 1.103 & 0.549 & 0.500 & 2.105 \\
\hline M1SAV_SA & 0 & 1.202 & 2.983 & 4.230 & 3.829 & 0 & 0.464 & 4.195 & 4.437 & 4.269 & 0 & 0.509 & 6.101 & 9.448 & 9.152 \\
\hline M2_SA & 0 & 4.927 & 13.976 & 17.656 & 15.471 & 0 & 11.638 & 16.854 & 11.655 & 19.004 & 0 & 11.691 & 16.935 & 10.971 & 13.193 \\
\hline DIVM2_SA & 0 & 1.454 & 3.958 & 2.402 & 4.793 & 0 & 4.755 & 9.576 & 5.878 & 7.006 & 0 & 5.541 & 11.560 & 8.527 & 8.196 \\
\hline DIVM2ATM_SA & 0 & 1.477 & 3.853 & 2.454 & 5.804 & 0 & 4.779 & 9.826 & 6.290 & 8.524 & 0 & 5.548 & 11.430 & 8.677 & 8.406 \\
\hline NEER_SA & 0 & 0.177 & 0.656 & 28.796 & 40.543 & 0 & 0.050 & 0.830 & 21.949 & 31.453 & 0 & 0.026 & 0.692 & 21.545 & 32.985 \\
\hline REER_SA & 0 & 0.036 & 0.615 & 15.336 & 29.472 & 0 & 0.249 & 1.795 & 10.377 & 19.517 & 0 & 0.060 & 1.117 & 9.190 & 19.882 \\
\hline SWAP_SA & 0 & 0.640 & 6.995 & 11.841 & 11.856 & 0 & 0.329 & 3.930 & 7.105 & 6.977 & 0 & 0.393 & 7.028 & 14.262 & 15.036 \\
\hline RC_INV & 0 & 0.725 & 2.660 & 3.822 & 3.245 & 0 & 0.158 & 4.330 & 8.062 & 7.726 & 0 & 0.341 & 5.628 & 11.857 & 12.387 \\
\hline RC_INV_SA & 0 & 0.696 & 2.367 & 3.506 & 2.974 & 0 & 0.124 & 4.168 & 8.246 & 7.938 & 0 & 0.285 & 5.610 & 12.234 & 12.810 \\
\hline RC_WC_SA & 0 & 0.256 & 10.470 & 15.265 & 13.802 & 0 & 0.159 & 10.492 & 16.567 & 15.917 & 0 & 0.318 & 15.344 & 25.649 & 25.575 \\
\hline RD1_SA & 0 & 0.659 & 5.538 & 9.481 & 9.797 & 0 & 1.257 & 2.035 & 4.721 & 4.809 & 0 & 1.067 & 3.505 & 10.107 & 10.879 \\
\hline RD3_SA & 0 & 0.624 & 0.364 & 0.375 & 0.360 & 0 & 6.280 & 1.892 & 0.801 & 0.925 & 0 & 5.476 & 1.183 & 1.230 & 1.201 \\
\hline RON_SA & 0 & 0.403 & 14.289 & 31.535 & 35.385 & 0 & 2.401 & 10.995 & 23.070 & 24.003 & 0 & 3.063 & 11.648 & 29.838 & 32. 554 \\
\hline SBI1M_SA & 0 & 1.226 & 0.579 & 0.262 & 0.229 & 0 & 0.474 & 0.161 & 0.174 & 0.216 & 0 & 0.307 & 0.088 & 0.128 & 0.141 \\
\hline SKDU_SA & 0 & 3.065 & 0.971 & 0.515 & 0.608 & 0 & 3.542 & 0.986 & 1.082 & 1.013 & 0 & 2.702 & 1.252 & 1.948 & 1.828 \\
\hline
\end{tabular}




\section{Grafik 1.}

Impulse Response Inflasi IHK terhadap variabel informasi (bivariate, 6 lags)
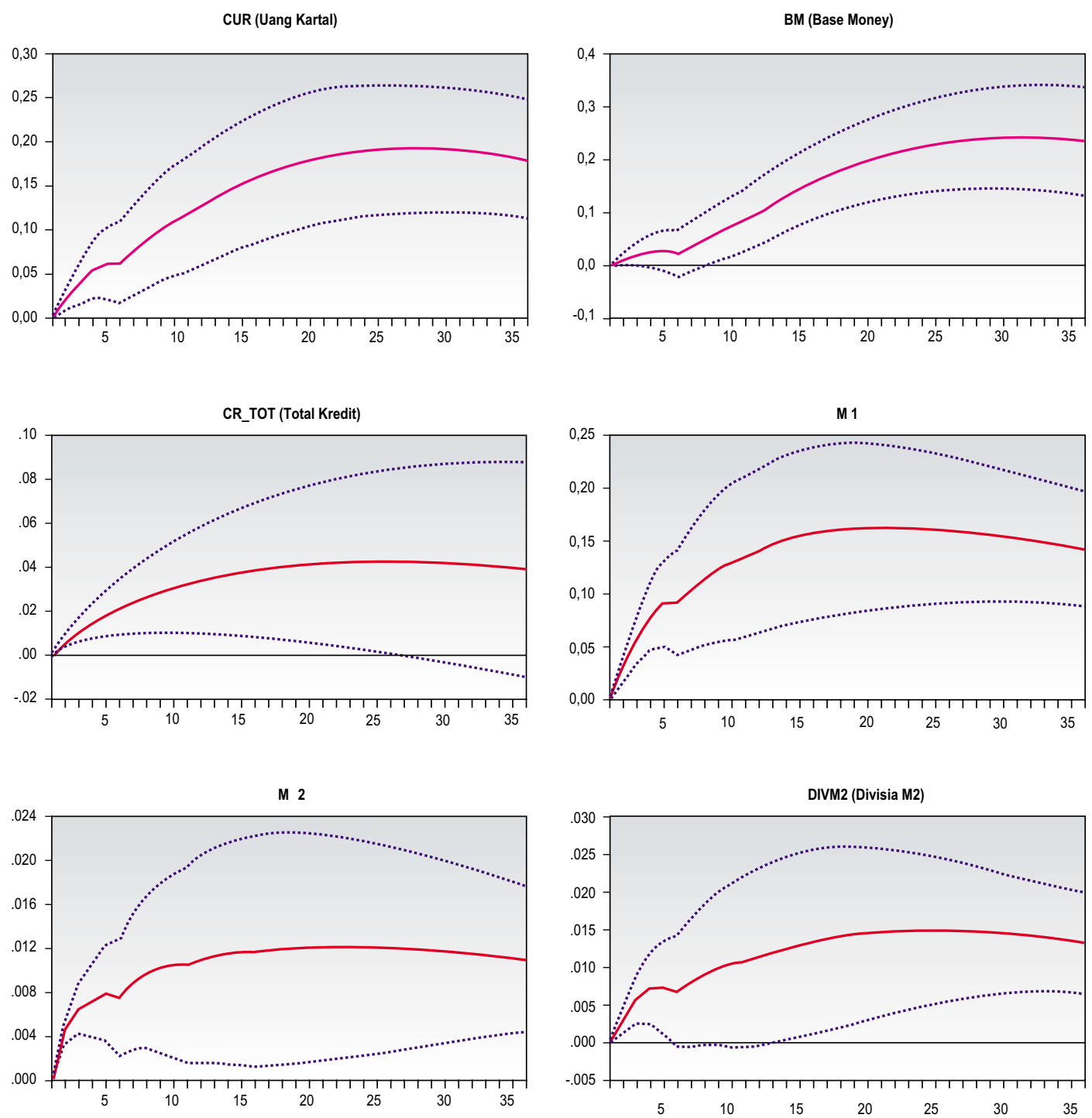


\section{Grafik 1. (lanjutan)}
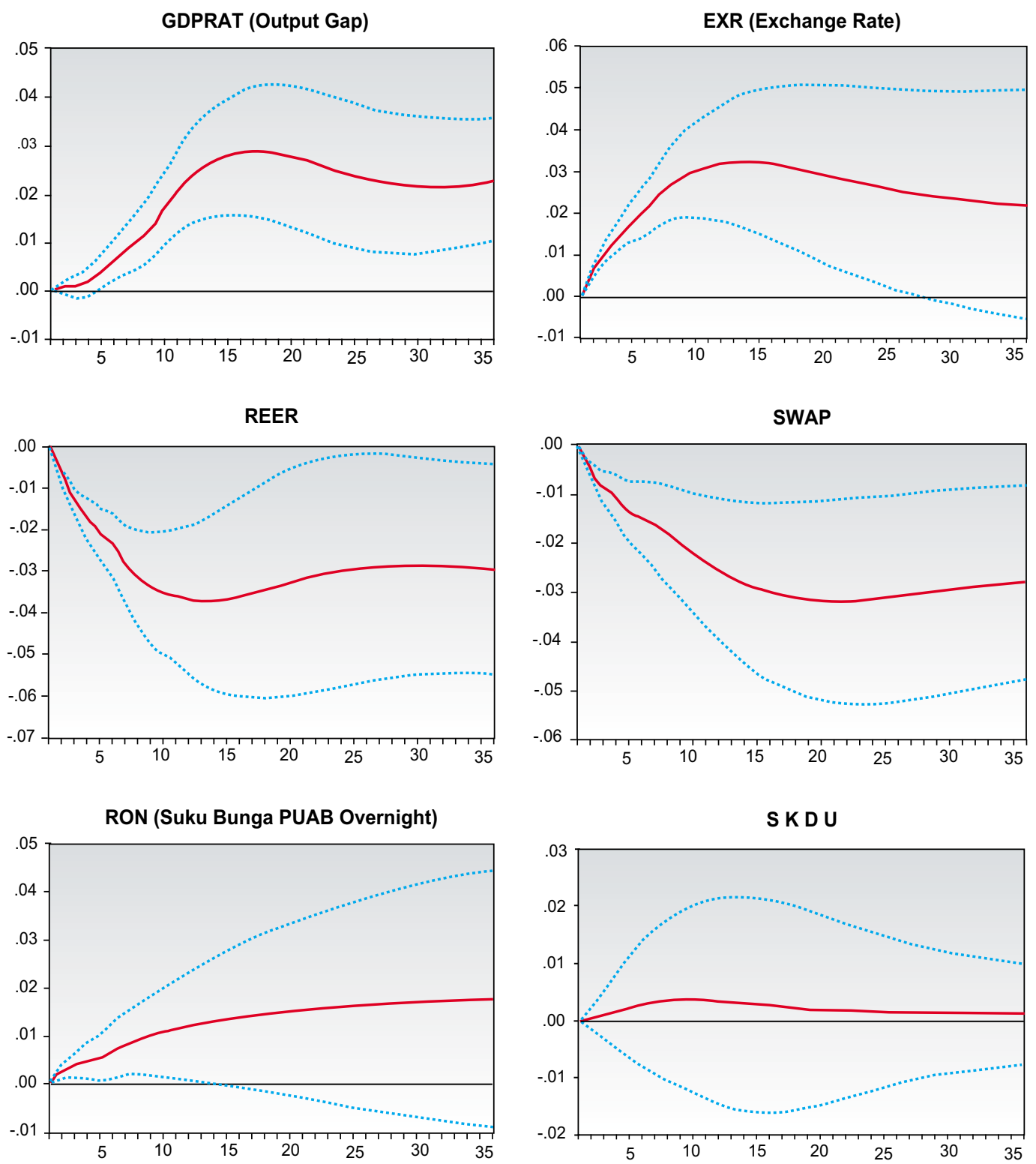


\section{References}

Alamsyah, H., Joseph, C., Agung, J., dan Zulverdy, D. (2001). Toward Implementation of Inflation Targeting in Indonesia. Bulletin of Indonesian Economic Studies, Dec.

Baumgartner, Josef and Ramana Ramaswamy (1996), Inflation Targeting in the United Kingdom: Information Content of Financial and Monetary Variables, IMF Working Paper, No.44.

Felman, J. (2000). Towards the Implementation of Inflation Targeting in Indonesia: Comments. Proceedings of an International Coneference on Monetary Policy and Inflation Targeting in Emerging Economies, Jakarta July 2000.

Friedman, Benjamin M. and Kenneth N. Kuttner (1992), Money, Income, Prices, and Interest Rates, The American Economic Review, pp. 472-492, June.

Friedman, Benjamin M.(1996), The Rise and Fall of Money Growth Targets As Guidelines for US Monetary Policy, NBER Working Paper, No.5465.

Tallman, Ellis W. and Naveen Chandra (1997), Financial Aggregates As Conditioning Information for Australian Output and Inflation, RBA Research Discussion Paper, No. 9704, Reserve Bank of Australia. 